\title{
UPBRINGING STUDENTS' VALUE ATTITUDE TO FUTURE PROFESSIONAL ACTIVITY IN SCIENTIFIC-PEDAGOGICAL HERITAGE OF UKRAINIAN SCHOLARS-PEDAGOGUES
}

The article deals with the problem of upbringing students' value attitude to work, future professional activity in a higher educational institution. On the basis of the analysis of the scientific-pedagogical heritage of Ukrainian scholars-teachers, the evolution of the socio-moral essence of work in the history of mankind, the transformation of awareness of work as a vital value in modern society has been presented. The theoretical foundations of the upbringing of the value attitude to work have been determined, the peculiarities of organization of upbringing process in higher educational institutions have been researched; the technology of organization of the process of upbringing students' value attitude to work in the conditions of a higher educational institution has been substantiated, the psychological-pedagogical conditions of its implementation have been characterized; the levels of formation student's value attitude to work has been defined on the basis of developed criteria and indicators; the essence of the technology of upbringing students' value attitude to work has been revealed.

Keywords: work, value attitude to work, higher educational institution, upbringing process, students, technology of upbringing students' value attitude to work.

Formulation of the problem. In the context of reforming and improving the education system it is necessary to appeal to Ukrainian scholars' historical heritage, in which the problems of the upbringing of students' value attitude to work, future professional activities in the higher educational institution are revealed. Research the experience of the past allows to study the historical patterns of formation and development of Ukrainian Pedagogy, to ensure the unity and continuity of the historical and pedagogical process. The humanistic orientation of modern education, aimed at children and youth mastering universal values, finding personal meanings in cognition, work, any other socially significant activity, is reflected in the new pedagogical concepts, the theory and practice of education. This is also highlighted in the main state documents - the Law "About Education", "Concept of Upbringing of Humanistic Values of Students", "Concept of Upbringing of Children and Youth in the National Education System". In today's society the problem of upbringing the younger generation's attitude to work becomes very important because it is caused by the change in the essence of the concept of work, the destruction, the transformation of its established categorical, meaningful and formal features.

The analysis of socio-pedagogical and psychological researches of the last decades confirms that in the process of upbringing of children and youth the meaning of the concept "work" is considered mainly in the context of familiarizing with the work of adults and the formation of certain labor abilities and skills. At the same time, labor upbringing of children and young people is impossible without value attitude to work, which requires its awareness as a way to overcome obstacles to learning or any other activity, process and result of making volitional efforts as an important condition for the formation of personal qualities - perseverance, responsibility, purposefulness. The upbringing value of attitude to work must begin as soon as possible, because hard working is one of the basic qualities of the child's personality.

The problem of forming a youth value attitude to work is also actualized by the situation of the diversification of types of educational institutions, which is characteristic of a modern stratified society. The problem of forming the values of Ukrainian youth and its highlighting in the pedagogical heritage of outstanding teachers is caused by the crisis realities of today's life, uncertainty in the future by modern youth, different theoretical approaches to consideration the problem of values, reforming higher education, changing the status of culture and the nature of human activity,and many other factors, which require not only certainty, viewing, reconsideration of the formation processes, the upbringing of children and youth, but also a thorough, objective analysis of our far and near past to better and deeper understanding of current events in this area of human activity that will make it possible to research problems of upbringing values of professional orientation of future professionals in higher education in Ukraine. That is why researches about the upbringing of students' value attitude to the future professional activity, to work in the scientific and pedagogical heritage of Ukrainian scholars and teachers in different periods of the development of education of the Ukrainian state will allow to select the optimal ways and mechanisms of effective development of the system of education of future specialists in higher educational institution under modern conditions of reforming the higher education of Ukraine in the context of integration into the European educational space.

Research goal and objectives. The purpose of the research is to reveal and substantiate the essence of the technology of upbringing value attitude to work, to the future professional activity of student youth in the conditions of a higher educational institution and in the scientific and pedagogical heritage of Ukrainian scholars and teachers. There are such objectives of the research: 1) to clarify the essence of the concept "value attitude to work" in relation to youth; 2) to generalize the experience and identify the peculiarities of the organization of the educational process of the higher educational institution concerning the formation of value attitude to work in youth; 3) to substantiate the technological model of upbringing students' value of attitude to work and the psychological and pedagogical conditions of its implementation.

Analysis of recent research and publications. In the scientific work of domestic and foreign researchers there are many works devoted to various aspects of labor upbringing: the role of labor upbringing in the overall development of personality (M. Drahomanov, G. Kerschenshteiner, A. Makarenko, L. Tolstoy, K. Ushinsky); a place of work in providing the multifaceted spiritual life of a person ( $P$. Blonskii, G. Skovoroda, R. Shteyner); the formation of value attitude to work (I. Bekh, R. Bure, V. Sukhomlynsky). Theoreti$\mathrm{cal}$ and methodological foundations of the formation of vital values (I. Bekh, V. Zinchenko, I. Zyazun, O. Savchenko, $\mathrm{N}$. Tkachev etc.) and values of the modern system of education and upbringing (A. Zdravomyslov, D. Leontiev, V. Ognevyuk, N. Shurkova, V. Yadov, E. Yamburg etc.) have been studied enough. Different aspects of the problem of formation of values and value attitudes of the personality have been highlighted in dissertation papers for recent years: emotional and value of attitude to educational activity (O. Kovshar, V. Kutishenko, S. Lupinovich, O. Khmelev); the value attitude to health ( $T$. Andrushchenko), to the native land (K. Shevchuk), to nature (L. Pavlov, T. Yurkova), to productive and family-labor work (V. Burdun, V. Kishkurno). Scientists have proved that the most sensitive age for the formation of value orientations is from 6 to 12 years 
(L. Bozhovich, L. Vygotsky, V. Davydov, D. Elkonin, O. Leontiev, V. Mukhina etc.).

Scientific researches of domestic and foreign scientists devoted to the study of the peculiarities of the organization of the educational process, which emphasize the peculiarity of the value orientations of children are important in context of our research (V. Alfimov, O. Gordeyev, O. Kobeleva, V. Pavlenko, M. Osorina, V. Spivakovsky, A. Chirikova). Despite the existing of a sufficiently wide range of studies that address this problem, the formation of students' value attitude to work in a higher educational institution has not been a subject of separate research.

The analysis of scientific pedagogical literature and the real practice of upbringing the value students' attitude to work has revealed a number of contradictions between: universal values ascertained by the society and the leveling of the role of work as the main value of life; declaring orientation to humanistic values and a formalized approach to the implementation of the axiological component in the practice of the educational institutions; the need in diverse types of educational institutions for a stratified society and the lack of development of educational technologies that take into account their specifics.

Study presentation. The study of work as a value, the analysis of the nature of work in different historical epochs, the dynamics of motives, content, types of labor activity, attitude to work, studying its role as a factor in the formation of personality was the subject of research in philosophy (A. Zaliskiy, F. Ilyasov, M. Kagan, T. Mikhailova); sociology (O. Drobnitsky, E. Durkheim, A. Zdravoimyslov, G. Becker, Y. Volkov, A. Ponukalin, I. Changli, V. Yadov); pedagogy (G. Beh, G. Belyanka, O. Bykovskaya, N. Shurkova), psychology (L. Bueva, L. Bozhovich, J. Krushelnytska, O. Leontyev, V. Myasishchev, N. Pryazhnikov, G. Rickert, V. Tolochek, D. Uznadze), axiology (M. Kagan, G. Chiziakova) and other sciences. Clarification of the etymology of concepts work, labor, and job made it possible to determine the common and different in understanding these concepts in languages and cultures of different times and peoples (I. Dubina, 3. Kozyreva, T. Myhaylova).

Based on the theoretical positions of the research, the essence of the key concept "work" has been clarified, which means active, purposeful activity that integrates the physical, mental and moral forces of a person for the creation of values or satisfaction of life's needs and the ability to overcome the difficulties to achieve the goal. The authors emphasize that it is the unity of the work of the body, the mind and the soul is the essence of the most diverse types of human work $[1 ; 3 ; 6 ; 7]$.

On the basis of the analysis of scientific literature, it was established that scientists had identified certain periods of the evolution of the moral essence of work, which was perceived in the primitive society as the main condition of survival, and subsequently, in the process of stratification of society, there was a gap between mental and physical labor, changed the understanding of the need to prepare young people for work, taking into account its specifics. Declaring the value of work in the medieval philosophy not only as a necessary way of life but also as a divine ordinance, the way of redemption of sins, the means of their prevention and overcoming was transformed in the era of the Renaissance into the perceived condition of "humanization" of a person, perfection, and, subsequently, the understanding of work as a social duty [2-6]. Consequently, the tracing of the dynamics of the socio-moral nature of work during the long process of social development made it possible to conclude that in the period of the establishment of the post-industrial community the essence of work continues to undergo significant transformations, it stopped to be the basis for the formation of a system of values that can be regarded to some extent as a moral catastrophe of society (U. Bek)

Work is considered [3, p. 707] as a conscious, purposeful human activity, aimed at creating socially significant material and spiritual values, necessary to meet the needs of the individual and society; it is the main form of life for a person and society, acts as a leading factor in sociogenesis; is a means of self-expression and self-affirmation of the person, realization of intellectual and creative potential, experience, a sense of moral dignity. Different needs, interests, inclinations, sense of duty, responsibility act as motives and cause a person to work. Work involves the presence of certain knowledge, abilities and skills, which are enriched and developed. In the process of work, the physical, spiritual, psychological and psychophysiological qualities of a person are formed. The labor process includes such elements as: a) purposeful employment; b) the object of the work; c) tools of labor; d) working conditions; e) result of labor. In reaching the goal, a person satisfies the most important needs and awareness of the goal is connected with the motive of work [3, p. 707].

In evolutionary and historical terms, work is a form of human activity. The structure of labor activity consists of the following elements: the need and motives of work; subject of work; purpose of work: conditions, methods, product of labor; social assessment of the contribution to the result of the work. In the process of achieving the results of the work there is a personal, professional growth of a person, which depends on the degree of versatility, productivity, creative nature of work. Work receives its true purpose only when it serves not only as a source of existence, but also a source of creative inspiration and pleasure [3, p. 708].

From the point of view of the socio-professional status of the youth, the majority of researchers consider the age from 15 to 28 years the border of young age. In this period, not only the professional formation of young people, but also the active formation of social maturity of the individual as a whole completes. In the context of the transition to market relations, young people get into the world of uncertainty. Particularly youth that begin their work suffer from it most of all. Under the conditions of the labor market and young people's competition, nobody guarantees the providing of well paid permanent job and everybody must be smart and flexible in finding a job. Changes in the way of life and consciousness of youth are the ambiguous and contradictory process. It is not always possible to say with certainty that individual psychological characteristics of the behavior of young people, formed in young age, will manifest themselves in the new social conditions. Young people are guided by the real situation on the labor market, where factors such as initiative, autonomy, organization, and creative attitude towards any, even the most diverse, work are at the first place. The leading place in the individual development of young people is independent labor activity. A young worker as a subject of labor, in addition to the availability of professional knowledge, skills and abilities, must be able to cooperate with the staff, to accept moral values and discover the essence of many events and facts of productive work life, to realize the significance of labor activity [3, p. 709].

Professional growth of young people goes both in the direction of improving the quality of implementation of already mastered professional operations, and by expanding the range of new technical and technological operations. This process is most intense in the first five years of independent professional work. Moreover, the greater correspondence between the individual-psychological characteristics of the person and the requirements of the profession to the employee, then it is more effective to include this person in the process of independent labor activity that is the reorganization of previously acquired labor experience in accordance with the immediate tasks with which a young worker meets 
at workplace. All experience is specified, specialized and overestimated in view of specific labor activity. The development of an unusual young worker's production schedule requires to re-evaluate the behavior, to refuse from certain habits, to collaborate with new people. The degree of use of potential opportunities for youth determines the effectiveness of using workforce and, to a large extent, the efficiency of production. The readiness and ability to work independently is determined by the following factors: a) physical and mental health: $b$ ) the level of general education and culture: c) the level of vocational training; d) professional values and orientations; e) high level of basic motivation (desire to work); e) moral maturity. A young worker must be a psychologist trained to work independently. This work must correspond to the basic requirements: a) be feasible, that is to correspond to individual psychological and physical capabilities; b) rational organization and normal working conditions; c) the nature of labor, which is constantly complicated: d) the possibility of manifestation independence, professional knowledge, skills and abilities in the process of work; e) prospects, social significance and value of work; $f$ ) the ability to demonstrate initiative and intelligence; g) systematic accounting and control over the performance of work, its timely evaluation; h) qualified guidance.

The process of adaptation of young people to work is directly influenced by the level of vocational education. The high level of general and vocational education of young people facilitates and accelerates adaptation. Young workers who have a basic education do their job well, which contributes to their professional growth. The prospect of professional self-affirmation, satisfaction with labor becomes important for young people. The prospect of professional selfaffirmation, success, recognition, interest in work, responsibility, professional growth are the main motivational factors for job satisfaction. The desire of young people to find their place in the labor market to assert themselves, to get the possibility to discover and realize their personal potential these are the main factors that determine the motivation of successful work.

An important mechanism for constructive transformation of the social and professional aspirations of young workers is the payment for labor. Young people are very sensitive to the social assessment of their work. Receiving a salary, a young worker at the same time gets extremely important information about his or her real value. Therefore, it is important to create a system of paying for work that can effectively stimulate the productivity of the youth work process, increase its competence. Young people come to the institution or to the company with their interests, life plans, professional plans, their own assessment of certain situations, phenomena. Labor activity becomes for them an environment for self-realization [3, p. 709].

Appealing to the understanding of labor as an universal value caused the necessity to highlight the nature and content of a number of axiological categories - "value", "value attitude", "value orientation", "sense of values" and so on. The problem of attitude to work as a value in a philosophical context was being researched by such prominent thinkers of the ancient world, as Aristotle and Plato, whose ideas were developed in the works of philosophers of a later period (I. Kant, R.Lottse, and modern scientists - A. Abishevoyi, V. Andruschenko, O. Drobnytskoho, M. Kahana, V. Olshanskoho, V. Partsvaniyi, Ch. Pirsa, V. Tuharynova, M. Haydehhera and others. The sociological aspect of the problem is highlighted in the works of S. Burilkina, Yu. Volkova, O. Drobnitsky, E. Durkheim, A. Zdravoumilov and others. Psycho-pedagogical aspects of the value of work were the focus in researches by I. Bekh, L. Bozhovych, L. Vyhotsky, D. Leontyev, O. Leontyev, V. Ohnevyuk, A. Makarenko, V. Sukhomlynsky, K. Ushynsky etc. [1-6].
It has been established that the concept "value attitude" is treated differently by scholars: as a personal meaning (V. Myasishchev, P. Pidkasisty), social connections of personality (B. Ananiev), an element of the inner world of personality (D. Leontyev), value orientation (A. Zdravoimyslov, V. Olshansky); "mental state" (V. Zobkov), "orientation of the person" (G. Boldireva, O. Leontyev), revealing of connections (N. Shurkova) etc. The generalization of different views has enabled 'to interpret the concept "value attitude" to work as an active, stable selective connection of the person with labor in all its manifestations, as a result work acquires for the subject personal sense, individual and social significance, provides moral, physical, mental and emotional satisfaction. Accordingly, the upbringing value attitude to work is understood as a complex, multifaceted, purposeful process of involving an individual into work, in which it acquires its own meaning of labor, accompanied by a change of motives, enrichment of knowledge, improvement of labor actions, the development of emotional-volitional and reflexive-evaluative spheres.

The application of a set of scientific approaches - systemic, axiological, activity-oriented, personally oriented made it possible to determine the theoretical foundations of the research problem and, accordingly, the basis for the substantiation of the technological model of students' value attitude to work in a higher educational institution. The importance of a systematic approach to the process of upbringing the value attitude to work is caused, first of all, by understanding of its social and ethical essence as a mechanism and, at the same time, a means of humanization; the necessity of ensuring the integral unity of purpose-oriented, content-active, emotional-volitional components of the process of upbringing value attitude to work (V. Afanasyev, I. Blauber, V. Sadovsky, E. Yudin etc.). Using the axiological approach, it was possible to outline the main psychological mechanisms of the investigated process, which ensures the conscious acceptance of work as the most significant vital value, to actualize the feeling of personal involvement in its social essence, create a certain ground for the development of the moral and spiritual needs of youth in the context of life-creation (N. Havrysh, I. Ivanov, V. Karakovsky, A. Kiriakova, E. Shiyanov, N. Shurkova, E. Yamkersburg) [3-5].

The education of value orientations and value attitude to work through the active inclusion of young people in various forms of labor interaction with peers and adults is characterized by the peculiarities of learning process as one of the most complex types of work, acquisition of skills of participation in collective labor, understanding of it as a guided process of personality development during student years $[1 ; 2 ; 6]$.

Studying the peculiarities of youth organization, in particular, the educational process in higher educational institutions (V. Alfimov, O. Burim, O. Dashkovskaya, V. Zhukov, G. Ionova, D. Podushkov, V. Spivakovsky, Yu. Fedorova, O. Khomyacov, M. Khromchenko etc.) made it possible to isolate its most characteristic features (maximum individualization of learning, atmosphere of "family comfort", comfortable staying, modern equipment, the lack of "distance" in relations "teacher - student", taking into account every student's interests and needs etc.) and benefits: favorable emotional atmosphere, close interaction between generations, teachers and parents in the context of a common information and spiritual space, high-quality resource base, certain groups, the ability to provide an individual approach to each student, a wide range of specialists, who are deeply engaged with students in various areas of acquiring education etc. (O. Borim, O. Vorobyov, Yu. Fedorov, I. Fedosov, L. Fomin, O. Cherdantsev etc.). Analyzing scientific literature and summarizing good practices of teachers in higher education it can be stated that there is unwillingness of the vast majority of young people to do various kinds of work, 
targeted application of their own efforts in general to overcome any difficulties, weak activity of their physical, mental and moral strength, low labor motivation $[2 ; 3 ; 6]$

In the development of theoretical models of technology upbringing value attitude to work the following positions have been determined: 1) components of value attitude to work (motivational, cognitive, activity, emotional-volitional and reflexive-evaluation) are closely interrelated and interdependent; 2) upbringing value attitude to work as a purposeful process associated with overcoming the difficulties, requires the unity of the physical, mental and moral forces of the personality, includes different types of work and permeates the entire process of young people life; 3 ) the peculiarities of the educational process in higher educational institutions are determined by the model of organization of their life, peculiar educational opportunities.

There are some basic principles of constructing upbringing work: principles of student's subjective position, orientation to the value of work, upbringing in activity, unity of upbringing influences. The conceptual idea of technology was the idea of gradual changes in the types of interaction of upbringing process (from the type of uncoordinated actions through the establishment of relationships between subjects to consolidation of the efforts of teachers and parents) in influencing the process of upbringing students' value attitude to work $[1 ; 4 ; 7]$.

In the structure of the model there are four interrelated components: purpose-oriented - reflects the gradual change of motives, the attitude of the student towards work, connected with the acquisition of its personal meaning, awareness of its significance in life; content-active - represents the main tasks of labor upbringing, connected with the awareness of work nature, types, work orientation, forms and methods of their implementation; emotional-volitional reflects the dynamics of changes connected with the admitting of work as necessary thing initially, the application of own efforts, when the personality enjoys the working process and organizational - defines the logic of deploying targeted upbringing process. Each of the interconnected components acquires special meaning at the successive stages of the implementation of the technology at the stage of immersion in work - overcoming the difficulties - the acquisition of personal meanings in labor. The model also shows a complex of psychological and pedagogical conditions for the implementation of technology: creating a situation of youth emotional feeling joy from work; delegation to students some organizational authorities in the preparation and conducting of various types of work in the upbringing process in higher educational institution; involvement of parents in the process of labor upbringing of youth. The process of implementation of the proposed technology is provided by the control and correction system. The model also reflects a set of appropriate tools for forming the value attitude to work. It should be noted that the peculiarities of the organization of upbringing work are connected with the specifics of the organization of youth life, the interaction between the individuals of the upbringing process, socio-psychological characteristics, value priorities of young people families.

The technology of upbringing the value attitude to work is based on the principles of upbringing in activity, the unity of educational influences, orientation on the value of labor and the individual position of the pupil; reflects the interconnection of structural components (purpose-oriented, content-active, emotional-volitional, organizational) and is accompanied by a change in the types of interaction between individuals of the upbringing process - from the uncoordinated through the establishment of personal contacts to the consolidation of efforts of teachers and parents.

It is worth to mention that the psychological and pedagogical conditions for the implementation of the technology of upbringing students' value attitude to work: the creation of a situation of young people emotional feeling the joy from work; delegation organizational things to students in the preparation and conduct of various types of work in the upbringing process of higher educational institutions.

It should be noted that the content-active component of the technology of upbringing the value attitude to work is characterized by overcoming difficulties with the joy provided by the formation of the volitional sphere of youth, their ability to overcome difficulties, a wide range of feelings and emotions from the process and the results of work.

The levels of formation of value attitude to work (high, medium, low) have been described on the basis of defined criteria and indicators (cognitive, characterized by a complex of knowledge about work, the completeness of knowledge about the value of work, awareness of the place of work in the life of a person and society; a motivationalassessment criterion, indicators of which were job motivation, the orientation of the person to master the skills, ability to the evaluation of the process and the result of the work and the work of others; emotional-volitional, which is characterized by the spectrum of emotions in different labor situations, the ability to overcome difficulties, the complex of moral qualities, among which there are the will, autonomy, organization, persistence, initiative etc.; activity criterion that is measured by the labor activity of children, the ability to work with subjects.

The successful implementation of the technology of upbringing the value attitude to work will be facilitated by the organization of such forms of upbringing work as the "Factory of Labor" and providing the complex of developed game-strategies, which at each stage of work have their content. Thus, the essence of forms and methods consists of filling the upbringing environment with different types of work under the direction of the teacher and the emotional feeling of the process and the result of work.

Conclusions. Theoretical analysis of the evolution of social-moral nature of work in human history, awareness of work as a social value in modern society has allowed to state transformation of the essence of this concept connected with the change of place and character of certain types of work in human life, changing its place and role in the system of values of the majority of members of society. Clarifying the concept of work made it possible to define it as an active purposeful activity that integrates physical, mental and moral child's forces to create values or satisfy vital needs and abilities to overcome difficulties to achieve the goal.

Definitional analysis of the concept "value attitude" from the perspective of different scientific approaches made it possible to distinguish its essential relationship with the concepts of "value", "value orientation", "personal meaning", "estimation" and to consider the best understanding of the value attitude to work as an active, sustainable selective connection of the person with work in all its forms. In the result work gets personal meaning for a person, individual and social significance, has moral, physical, mental and emotional satisfaction. The structural components of value attitude to work are determined: cognitive, motivational, appraisal, emotional-volitional and activity.

The psychological-pedagogical conditions of realization of technology of upbringing value attitude to work in student's youth are: creation of a situation of emotional feeling joy from work; delegation to students organizational work in the preparation and conduct of various types of work in the educational process of higher educational institution. Consideration of the above-mentioned questions does not cover all aspects of the researched problem, which allows to outline the perspective directions of scientific search, connected with the study of the 
value attitude to work in future teachers and the training of pedagogical staff for the organization of upbringing work in different types of educational institutions.

References

1. Bekh I. D. Vykhovannia osobystosti: [navch. posibnyk] / I.D.Bekh. Kyiv.: Lybid, 2008. - 848 s.

2. Hordieieva K. S. Profesiini tsinnosti v systemi sotsialno-pedahohichnoi roboty: psykholohichnyi aspekt / K. S. Hordieieva // Humanizatsiia navchalnovykhovnoho protsesu: zbirnyk naukovykh prats / [za zah. red. prof. V. I. Sypchenka] - Slovyiansk: DDPU, 2014. - Vypusk LXVIII. - Ch. I. - S. 182 - 188.

3. Entsyklopediia osvity [entsyklopediia] / V.H.Kremen. - Kyiv: Yurinkom Inter, 2008. - $1040 \mathrm{~s}$

4. Etyka: [navch posibnyk] / V O.Lozovoi, M.I.Panov, O.A.Stasevska ta in K.: Yurinkom Inter, 2002. - 224 s. - S. 103

5. Kalashnikova L.U. Umovy formuvannia sotsialnoi pozytsii studenta / L.U.Kalashnikova // Pedahohika ta psykholohiia. 2014. - Vyp. 45. - S. 125-134.

6. Solovei M.I., Kudina V.V., Spitsyn le.S. Profesiino-pedahohichna pidhotovka maibutnoho vchytelia $v$ kredytno-modulnii systemi orhanizatsii navchannia: [navchalnyi posibnyk] / M.I.Solovei, V.V.Kudina, Ye.S.Spitsyn. Kyiv: Lenvit, 2013. -414 s. - S.148
7. Tsinnosti osvity i vykhovannia: [navch. posibnyk] / O.V.Sukhomlynska. Kyiv, 1997.

Список використаних джерел

1. Бех І.Д. Виховання особистості : навч. посіб. / І.Д. Бех. - К. : Либідь, 2008. -848 c.

2. Гордєєва К.С. Професійні цінності в системі соціально-педагогічної роботи: психологічний аспект / К.С. Гордєєва // Гуманізація навчальновиховного процесу: зб. наук. пр. ; за заг. ред. проф. В.І. Сипченка. Слов'янськ : ДДПУ, 2014. - Вип. LXVIII. - Ч. І. - С. 182-188.

3. Енциклопедія освіти : енциклопедія / В.Г. Кремень. - К. : Юрінком Інтер, 2008. - 1040 c.

4. Етика : навч. посіб. / В.О. Лозовой, М.І. Панов, О.А. Стасевська та ін. - К. Юрінком Інтер, 2002 - 224 с. - С. 103

5. Калашнікова Л.Ю. Умови формування соціальної позиції студента / л.Ю. Калашнікова // Педагогіка та психологія, 2014. - Вип. 45. - С. 125-134.

6. Соловей М. І. Професійно-педагогічна підготовка майбутнього вчителя в кредитно-модульній системі організації навчання : навч. посіб. / М.І. Соловей, В.В. Кудіна, Є.С. Спіцин. - К. : Ленвіт, 2013. - 414 с. - С. 148.

7. Сухомлинська О.В. Цінності освіти і виховання : навч. посіб. / О. В. Сухомлинська. - К., 1997

Надійшла до редколегії 05.02.19

Л. Левицька, канд. пед. наук, доц.

Київський національний університет імені Тараса Шевченка, Київ, Україна

\section{ВИХОВАННЯ У СТУДЕНТСЬКОЇ МОЛОДІ ЦІННІСНОГО СТАВЛЕННЯ ДО МАЙБУТНЬОЇ ПРОФЕСІЙНОЇ ДІЯЛЬНОСТІ В НАУКОВО-ПЕДАГОГІЧНІЙ СПАДЩИНІ УКРАЇНСЬКИХ УЧЕНИХ-ПЕДАГОГІВ}

Окреслено проблему виховання у студентської молоді ціннісного ставлення до праці, майбутньої професійної діяльності в умовах закладу вищої освіти. На основі аналізу науково-педагогічної спадщини українських учених-педагогів представлено еволюцію соціальноморальної сутності праці в історії людства, трансформацію усвідомлення праці як життєвої цінності в сучасному суспільстві. Охарактеризовано працю як свідому цілеспрямовану діяльність, що інтегрує фізичні, розумові та моральні сили людини задля створення цінностей, задоволення потреб; виступає провідним фактором соціогенезу; є засобом самовираження та самоствердження особистості, реалізації її інтелектуального і творчого потенціалу, досвіду, почуття моральної гідності. Визначено елементи структури трудової діяльності та чинники готовності, здатності особистості до ефективної самостійної праці. Розкрито сутність поняття "ціннісне ставлення до праці" як особистісний смисл, соціальні зв'язки особистості, елемент внутрішнього світу особистості, ціннісна орієнтація; "психічний стан", "спрямованість особистості", виявлення зв'язків; як активний, стійкий вибірковий зв'язок суб'єкта з працею в усіх її проявах. З'ясовано сутність категорії "виховання ціннісного ставлення до праці" як складний, багатогранний, цілеспрямований процес залучення особистості до трудової діяльності. Визначено теоретичні засади виховання ціннісного ставлення до праці у студентської молоді, досліджено особливості організації виховного процесу в закладах вищої освіти. Обґрунтовано технологію та модель виховання ціннісного ставлення до праці у студентської молоді, що включає взаємопов'язані компоненти (цілемотиваційний; змістовно-діяльнісний; емоційно-вольовий та організаційний) і комплекс психолого-педагогічних умов реалізації технології виховання у студентської молоді ціннісного ставлення до праці (створення відчуття радості праці; делегування студентам організаційних повноважень у підготовці і проведенні різних видів роботи в освітньому процесі закладу вищої освіти).

Ключові слова: праця, ціннісне ставлення до праці, заклад вищої освіти, виховний процес, студентська молодь, технологія виховання у молоді ціннісного ставлення до праці.

\section{EDUCATIONAL SPHERE SPECIALISTS PREPARATION ON THE EXAMPLEOF MULTIDIMENSIONAL E DUCATIONAL AND ENLIGHTENMENT ACTIVITIES OF SIDOR VOROBKEVICH}

The article presents the study of Sidor Vorobkevych educational activities in the multicultural environment of Austrian Bukovina. Under such conditions, study of the creativity and activity of such a multidimensional and multicultural personality as Sidor Vorobkevich is especially topical. After all, he lived and worked at such time and territory when the agreement was reached between people of different ethnic groups, different cultures, values, religion. Conducted parallel with the modern tasks of education and society development and proposed their solution on the example of S. Vorobkevich's activities, such as modern historians consider Austrian Bukovina like a kind of prototype of the European Union. In Soviet times, his name and works were either completely ignored or interpreted pre-conceived. It was inadmissible that he had a sacerdotal rite and teaching in theological seminary and theological faculty of Chernivtsy University, what contradicts to communists ideology. His pedagogical work started in theological seminary, real school, gymnasium and dascalia (deacon school) in Chernivtsi, where he had up to 40 training hours per week. Having entered the post of teacher of music and singing of the theological seminary, S. Vorobkevich encountered a number of problems that required an urgent solution like absence of any teaching and methodological base - textbooks on musical literacy and solfeggio, didactic instructions for teaching singing, a collection of songs for the school repertoire. The young teacher starts solving the situation on his own. He had to create everything in the process of work. Slowly he wrote plenty of manuals for studying music and languages (he wrote in Ukrainian, Romanian, German). His manuals were used not only in Bukovina and in Ukraine, but also far beyond its borders. In the article we conduct the parallel with the image of modern teacher tolerant, creative, developed, multidimensional person, as teacher should be.

Keywords: Multiculturalism, Tolerance, Sidor Vorobkevich, Bukovina, educational and enlightenment activities.

Formulation of the problem. In recent years, violent extremism and terrorist attacks have erupted in Europe and US, it is causing a threat not only to the security of its citizens, but also to its basic values of freedom, democracy, equality, respect for dignity and human rights. Disturbing events directly oppose the vision of a Western society characterized by pluralism, non-discrimination, tolerance, justice, solidarity 